\title{
CHARACTERIZATION MORPHOAGRONOMIC OF GUAVA FRUITS UNDER DIFFERENT WATER DEPTHS AND NITROGEN FERTLIZATION LEVELS ${ }^{1}$
}

\author{
JOSÉ DANTAS NETO ${ }^{2 *}$, AARON DE SOUSA ALVES ${ }^{3}$, CARLOS ALBERTO VIEIRA DE AZEVEDO², PEDRO \\ DANTAS FERNANDES ${ }^{2}$, VERA LÚCIA ANTUNES DE LIMA ${ }^{2}$
}

\begin{abstract}
The objective of this study was to evaluate the effects of different water depths and nitrogen fertilization levels applied by fertigation on the physical attributes of guava fruits $\mathrm{cv}$. Paluma. The study was carried out taking into account factors water depths $(1144,1465,1785$ and $2106 \mathrm{~mm})$ and nitrogen fertilization levels $\left(50,100,150\right.$ and $\left.200 \mathrm{~kg} \mathrm{ha}^{-1}\right)$. The water depths 1730 and $1750 \mathrm{~mm}$ increased production and the average weight of guava fruit in, respectively, 25.1 and $31.6 \%$. The applications 178 and $152 \mathrm{~kg} \mathrm{~N} \mathrm{ha}^{-1}$ increased at $67.1 \%$ in the production of fruits and $16.3 \%$ the average fruit weight. The combined application of $150 \mathrm{~kg} \mathrm{~N} \mathrm{ha}^{-1}$ and $1789 \mathrm{~mm}$ of water amounted to $63.3 \%$ of the total weight of fruit. The equatorial diameter of the fruit was influenced by individual water depths applied evidencing an increase of up to $26.8 \%$. Already combinations $200 \mathrm{~kg} \mathrm{~N} \mathrm{ha}^{-1}$ and $1746 \mathrm{~mm}$ of water increased the longitudinal diameter of the fruits by $18.77 \%$. The application of water depth to $1144 \mathrm{~mm}$, associated with $143 \mathrm{~kg} \mathrm{~N} \mathrm{ha}^{-1}$ gave index of the most satisfactory way to guava fruit.
\end{abstract}

Keywords: Psidium guajava L. Irrigated fruit culture. Located Irrigation.

\section{CARACTERIZAÇÃO MORFOAGRONOMICA DE FRUTOS DE GOIABEIRA SUBMETIDA A DIFERENTES LÂMINAS DE ÁGUA E ADUBAÇÃO NITROGENADA}

\begin{abstract}
RESUMO - Objetivou-se com este estudo avaliar os efeitos de diferentes lâminas totais de água e níveis de adubação nitrogenada, aplicados via fertirrigação, sobre os atributos físicos de frutos de goiabeiras cv. Paluma. O estudo foi conduzido levando-se em consideração os fatores lâminas de água $(1144 ; 1465 ; 1785$ e 2106 mm) e doses de nitrogênio $\left(50 ; 100 ; 150\right.$ e $\left.200 \mathrm{~kg} \mathrm{ha}^{-1}\right)$. As lâminas de água 1.730 e $1.750 \mathrm{~mm}$ aumentaram a produção e o peso médio de frutos de goiabeira em, respectivamente, 25,1 e 31,6\%, já as aplicações de 178 e $152 \mathrm{~kg}$ de $\mathrm{N} \mathrm{ha}^{-1}$ elevaram em $67,1 \%$ a produção de frutos e em $16,3 \%$ o peso médio de frutos. As aplicações combina-

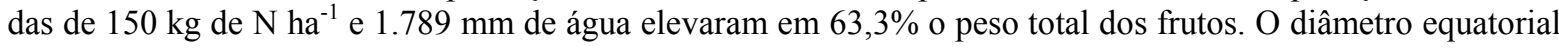
dos frutos foi influenciado isoladamente pelas lâminas de água aplicadas constatando-se um aumento de até $26,8 \%$. Já as combinações $200 \mathrm{~kg}$ de $\mathrm{N} \mathrm{ha}^{-1}$ e $1.746 \mathrm{~mm}$ de água incrementaram o diâmetro longitudinal dos frutos em 18,77\%. A aplicação da lâmina de água correspondente a $1.144 \mathrm{~mm}$, associada a $143 \mathrm{~kg} \mathrm{de} \mathrm{N} \mathrm{ha}^{-1}$ conferiram índice de forma mais satisfatório aos frutos de goiabeira.
\end{abstract}

Palavras-chave: Psidium guajava L. Fruticultura irrigada. Irrigação localizada.

\footnotetext{
*Corresponding author

${ }^{1}$ Received for publication in $12 / 03 / 2013$; accepted on $07 / 04 / 2015$.

${ }^{2}$ Prof. Dr., Graduate Program in Agricultural Engineering, Federal University of Campina Grande - CTRN/ UFCG. Rua Aprígio Veloso, CEP: 58109-970, Campina Grande (PB).

${ }^{3}$ Agronomist, Master in Agricultural Engineering, Federal University of Campina Grande - UFCG/CTRN. Rua Aprígio Veloso, CEP: 58109-970, Campina Grande (PB); zedantas1955@gmail.com.
} 


\section{INTRODUCTION}

The cultivation of potentially economic species to serve various purposes requires technical knowledge not always available. The adequate supply of water and nutrients to crops through irrigation is one of the many difficulties of this process, demanding from researchers and scientists, appropriate management techniques to provide efficient and safe quality control, especially when dealing with cultures of high economic importance, such as the guava culture.

Brazil has huge areas of climate and soil favorable to the commercial production of guava, which is important not only due to the nutritional value of this fruit, but also from the perspective of increasing the agricultural production, the expansion of the industrial activity and export potential (ROZANE; OLIVEIRA; LIRIO, 2003). Generating jobs, food, income and other key elements for improving the living conditions of the population (SOBEL; COSTA, 2005; XAVIER; COSTA; COSTA, 2006). Thus, the guava culture has become of great importance in several regions of Brazil, mainly in the state of São Paulo, the largest national producer (PEREIRA; CARVALHO; NACHTIGAL, 2003). Where there are several areas cultivated with this culture, which is a great option for the diversification of the regional fruit farming activity (CARVALHO et al., 2006).

In the Brazilian semiarid region, mainly in regions where rainfall is insufficient to meet the water needs of crops, agricultural activities under irrigated conditions have become an economically viable alternative; however, there is need to find alternatives that minimize production costs. The supply of nutrients to the crop through irrigation in adequate amounts and at the right moment seems to be an economically viable and environmentally friendly technological alternative for the guava production process.

Lousada Júnioret al. (2006) have reported a professionalization process, characterized by the exploitation of more extensive areas, use of irrigation and the development of new technologies aiming at increasing the production of fruits. In this sense, Teixeira; Quaggio and Mellis (2011) reported that irrigation and fertilization are essential for the practice of intensive agriculture. However, special attention should be paid to the use of nutrients used to increase production efficiency, quantifying appropriate levels and knowing the magnitude and speed of their transformation (ALVES et al., 2010). Thus, many countries have adopted production through new soil and water management techniques, providing not only increased yields, but also the optimal use of natural resources (FARIAS et al., 2003).

Although fertigation has been used in some irrigated areas in Brazil, the lack of information, especially about dosages, most recommended type of fertilizer, prevention of precipitates and method and time of application reflect the need for research in this area, considering the diverse conditions of the country (PEIXOTO; GUERRA; CHAVES, 2006). However, its use requires improvements in the application techniques so that producers can obtain a maximum economic benefit by using this fertilizer (ALVES et al., 2010).

Thus, this study was aimed at assessing the effects of different water depths and nitrogen fertilization levels applied by fertigation on the physical attributes of guava fruits (Psidium guajava L.) cv Paluma with four years of age.

\section{MATERIAL AND METHODS}

The studies with the P. guajavacv. Paluma with four years of age were carried out at field level, under normal conditions of temperature, photoperiod and relative humidity at the Experimental Station of Veludo $\left(07^{\circ} 18^{\prime} 00^{\prime \prime} \mathrm{S}\right.$ and $\left.38^{\circ} 09^{\prime} 00^{\prime \prime} \mathrm{W}\right)$ at the Experiment Station of the State Enterprise for Agricultural Research of Paraiba - EMEPA, municipality of Itaporanga, PB. The study site is $291 \mathrm{~m}$ above sea level.

According to the Köppen climate classification, the climate in the region is type AW', hot and humid with summer and autumn rains. The rainy season starts in January and ends in April, and the driest months are from June to December. With rainfalls $806 \mathrm{~mm}$ annual, average temperature of about $24^{\circ} \mathrm{C}$ and relative humidity of around $73.8 \%$. The pluviometric precipitations events in the region during the conduct of experiments are shown in Figure 1.

The guava crop was planted in a single row, with spacing of $6.0 \mathrm{~m}$ between rows and $5.0 \mathrm{~m}$ between plants in a neosol of typically plan relief, in which several simple samples were collected at different depths: $0-20$ and $20-40 \mathrm{~cm}$, in order to compose a composite sample for each specified depth, which were properly identified and referred for physical and chemical characterization, Tables 1 and 2, at the Laboratory of Irrigation and Salinity (LIS) Federal University Campina Grande (UFCG) in order to determine the phosphorus and potassium levels of to be applied to the soil. 


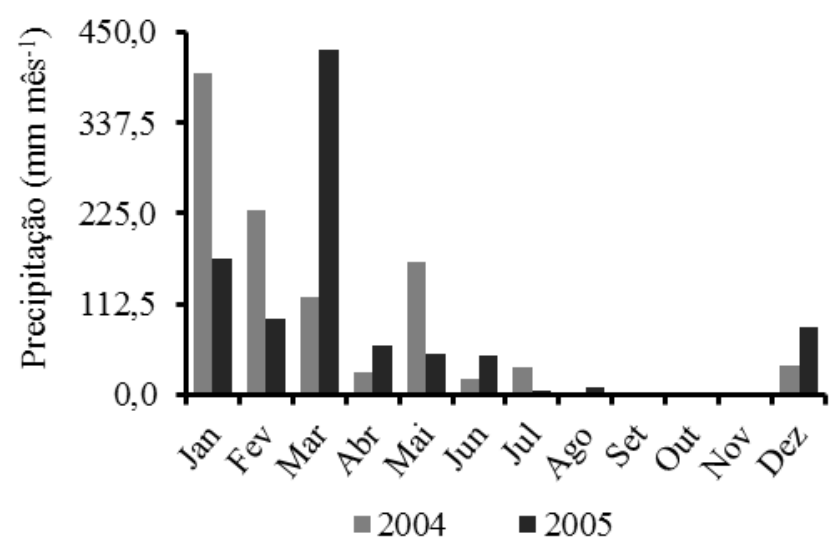

Figure 1. Pluviometric precipitations occurred in the region during the experimental period

Table 1. Physical characterization of soils cultivated with guava (Psidium guajava L.) cv Paluma.

\begin{tabular}{|c|c|c|c|}
\hline \multirow{2}{*}{ Characteristics } & \multirow{2}{*}{ Unity } & \multicolumn{2}{|c|}{ Depths (cm) } \\
\hline & & $0-20$ & $20-40$ \\
\hline Sand & $\mathrm{g} \mathrm{kg}^{-1}$ & 418.9 & 446.1 \\
\hline Silt & $\mathrm{g} \mathrm{kg}^{-1}$ & 269.2 & 281.5 \\
\hline Clay & $\mathrm{g} \mathrm{kg}^{-1}$ & 311.9 & 272.4 \\
\hline Texture & - & Clay-loam soil & Clay-loam soil \\
\hline Soil density & $\mathrm{g} \mathrm{cm}^{-3}$ & 1.29 & 1.27 \\
\hline Particle density & $\mathrm{g} \mathrm{cm}^{-3}$ & 2.77 & 2.76 \\
\hline Total porosity & $\%$ & 53.42 & 53.98 \\
\hline
\end{tabular}

Table 2. Chemical characterization of soils cultivated with guava (Psidium guajava L.) cv Paluma.

\begin{tabular}{|c|c|c|c|c|c|c|c|c|c|c|}
\hline \multirow{2}{*}{ Depths $(\mathrm{cm})$} & $\mathrm{pH}$ & M.O. ${ }^{1}$ & $\mathrm{P}$ & $\mathrm{K}$ & $\mathrm{S}$ & $\mathrm{Ca}$ & $\mathrm{Mg}$ & $\mathrm{H}+\mathrm{Al}$ & $\mathrm{Na}$ & \multirow{2}{*}{$\begin{array}{c}\mathrm{EC}^{2} \\
\mathrm{dS} \mathrm{m}{ }^{-1}\end{array}$} \\
\hline & $\mathrm{H}_{2} \mathrm{O}$ & $\mathrm{g} / \mathrm{kg}$ & \multicolumn{4}{|c|}{$\ldots \ldots \ldots \mathrm{mg} \mathrm{dm}^{-3} \ldots \ldots \ldots$} & \multicolumn{3}{|c|}{.........cmol dm ${ }^{-3} \ldots \ldots \ldots \ldots$} & \\
\hline $0-20$ & 8.07 & 1.03 & 14.55 & 148.58 & 16.73 & 6.8 & 7.68 & 0.0 & 1.87 & 0.30 \\
\hline $20-40$ & 7.40 & 0.65 & 11.37 & 125.12 & 17.45 & 7.2 & 7.88 & 0.0 & 2.05 & 0.33 \\
\hline
\end{tabular}

${ }^{1}$ M.O.: Organic Matter; ${ }^{2}$ EC: Electrical Conductivity

The crop was irrigated by a sprayer-type drip irrigation system operated by a three-phase electric motor pump, type KSB, with power of $3 \mathrm{hp}$, speed of $3450 \mathrm{rpm}$ and flow rate of $15 \mathrm{~m}^{3} \mathrm{~h}^{-1}$, main pipeline made with PVC and access to each experimental plot consisting of flexible polyethylene hoses with 16 $\mathrm{mm}$ in diameter containing self-compensating micro sprinklers with nominal flow rate of $50 \mathrm{~L} \mathrm{~h}^{-1}$, working pressure of $250 \mathrm{kPa}$, providing a wet radius of $2.5 \mathrm{~m}$, with one micro sprinkler at each plant.

Irrigation was performed daily after pruning in two productive cycles that lasted, respectively, 202 and 200 days. The irrigation was calculated based on the daily evaporation from tank class A, according to the methodology proposed by Maciel; Dantas Neto e Fernandes (2007). The irrigation level applied was a result of the irrigation plus effective precipitation $(\mathrm{Pe})$, the latter being obtained according to Blaney and Criddle (1962).

The experimental design used in this study was randomized blocks with treatments arranged in a $4 \times 4$ factorial, with 4 water depths and 4 nitrogen levels, resulting in 16 treatments with four replicates each, thus making 64 experimental plots with two plants each.

The water depths applied (TD) corresponded to $1144,1465,1785$ and $2106 \mathrm{~mm}\left(\mathrm{~L}_{1}, \mathrm{~L}_{2}, \mathrm{~L}_{3}\right.$, and $\mathrm{L}_{4}$, respectively) and nitrogen levels $(\mathrm{N})$ were 50 , 100,150 and $200 \mathrm{~kg} \mathrm{ha}^{-1}\left(\mathrm{~N}_{1}, \mathrm{~N}_{2}, \mathrm{~N}_{3}\right.$ and $\mathrm{N}_{4}$, respectively) applied in the form of potassium nitrate and urea through fertigation, three times per week during the production cycle of the culture, and to this end, a venturi-type fertilizer injector with flow rate of approximately $900 \mathrm{ml} \mathrm{min}^{-1}$ was used.

From the results of soil analyzes and fertilization suggested for the cultivation of guava, $60 \mathrm{~kg} \mathrm{ha}^{-1}$ of $\mathrm{P}_{2} \mathrm{O}_{5}$ were applied in the form of simple superphosphate and $90 \mathrm{~kg} \mathrm{ha}^{-1} \mathrm{~K}_{2} \mathrm{O}$ as potassium nitrate. The first was applied in coverage after pruning at a dosage of $0.8 \mathrm{~kg}$ plant $^{-1}$. The second, by having nitrogen in its composition, had the value corresponding to this nutrient supplemented with urea, in amounts that were calculated according dosages already specified in this study for Nitrogen $(\mathrm{N})$, according to each experimental treatment.

The physical characteristics of fruits were 
determined during the harvest period, considering the following parameters: number of fruits per plant (NF), total fruit weight per plant (TW), average fruit weight (AW), equatorial diameter (ED), longitudinal diameter (LD) and shape index (SI).

Results were submitted to analysis of variance and polynomial regression, evaluating the effects of each factor alone, as well as the interaction between them using the SISVAR statistical package.

\section{RESULTS AND DISCUSSION}

The results shown in Table 3 correspond to analysis of variance of the following physical attributes: number of fruits per plant (NF), total fruit weight per plant (TW), average fruit weight (AW), Equatorial Diameter (DE) Longitudinal diameter (DL) and shape index (SI) of guava fruits cv. Paluma.

Table 3. Summary of the analysis of variance for the following variables: number of fruits per plant (NF), total fruit weight (TW) in $\mathrm{kg} \mathrm{plant}^{-1}$ and average fruit weight (AW) in $\mathrm{kg}$, equatorial diameter (ED) and longitudinal diameter (LD) in $\mathrm{mm}$, and shape index (SI).

\begin{tabular}{lccccccc}
\hline \multirow{2}{*}{ Source of variation } & GL & \multicolumn{5}{c}{ Average square } \\
\cline { 3 - 7 } & & NF & TW & AW & DE & DL & SI \\
\hline Irrigation level (L) & 3 & $23841.52^{* *}$ & $4046.86^{* *}$ & $0.0089^{* *}$ & $140.9^{* *}$ & $282.5^{* *}$ & $61.8^{\text {ns }}$ \\
Nitrogen (N) & 3 & $58505.72^{* *}$ & $4315.75^{* *}$ & $0.0028^{*}$ & $27.2^{\mathrm{ns}}$ & $291.5^{* *}$ & $287.2^{* *}$ \\
L x N & 9 & $3571.22^{\mathrm{ns}}$ & $440.57^{* *}$ & $0.0012^{\mathrm{ns}}$ & $9.7^{\mathrm{ns}}$ & $44.0^{\mathrm{ns}}$ & $62.6^{\mathrm{ns}}$ \\
Block & 3 & $1742.26^{\mathrm{ns}}$ & $92.42^{\mathrm{ns}}$ & $0.0002^{\mathrm{ns}}$ & $6.0^{\mathrm{ns}}$ & $14.7^{\mathrm{ns}}$ & $18.4^{\mathrm{ns}}$ \\
Residue & 45 & 1885.22 & 62.79 & 0.0006 & 12.83 & 34.0 & 27.8 \\
VC (\%) & & 10.62 & 10.00 & 12.84 & 6.80 & 5.50 & 12.20 \\
\hline
\end{tabular}

$*$ and $* *$ significant at $1 \%$ and $5 \%$ probability, respectively, ns - not significant.

Except for the shape index (SI), the other variables were significantly influenced the $1 \%$ probability level by water depths applied. An isolated effect was observed at $1 \%$ probability level of factor nitrogen fertilization levels on variables number of fruits per plant (NF), total fruit weight (TW), Longitudinal Diameter (LD) and shape index (SI), and at $5 \%$ probability level on the average fruit weight (AW). Among the variables analyzed, only the total fruit weight per plant (TW) was significantly influenced by the interaction between water depths and nitrogen fertilization levels by the $\mathrm{F}$ test at $1 \%$ probability.

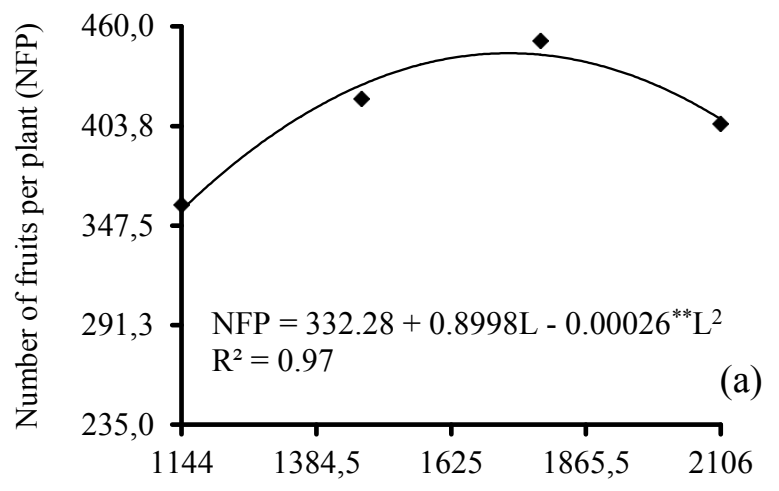

Total water depth : irrigation+precipitation (mm)
According to results obtained from the regression studies, there was a linear and quadratic response with a significant effect of factors on the variable number of fruits per plant (NF) at $1 \%$ probability level. Thus, according to the statistically significant models found in this study, the quadratic was chosen because it was the one that best fit the nature of factors studied, as well as its dispersion coefficient $\left(r^{2}\right)$.

Figure 2 shows the isolated effect of different irrigation and nitrogen fertilization levels on the number of fruits per guava plant (NF).

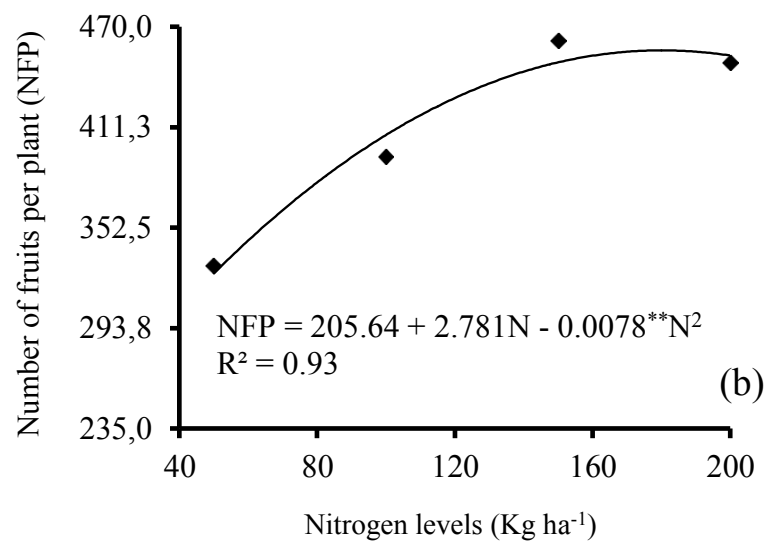

Figure 2. Number of fruits per guava plant (Psidium guajava L.) as a function of water depths (a) and nitrogen fertilization levels (b) 
Thus, based on results and according to the quadratic statistical model obtained for this factor (Figure 2a), it was observed that the highest physical performance was obtained when water depth corresponding to $1730 \mathrm{~mm}$ was applied, providing 446 fruit per P. guajava plant. This value represents an increase of $25.1 \%$ in crop production compared to the lowest water depth and of $8.2 \%$ compared to the greatest water depth adopted in this study.

Reductions in the number of fruits per plant provided by water depths corresponding to minimum and maximum applied to the culture probably were not only due to water deficit provided by the first, but also due to excess water applied through the highest irrigation level adopted in this study, which also caused a reduction in the number of fruits per guava plant.

In general, water depths tested in this study significantly influenced the $P$. Guajava production. Albrigo (1992) emphasized that water influences all fruiting stages of crops and irrigation is the cultural practice that most affects fruit development. Thus, the knowledge on the maximum daily and total annual water requirements of a given culture allows estimating the total volume of water that should be applied to meet the water needs (FREITAS; RAMOS; COSTA, 2008). Since water supplied through irrigation promotes optimal plant development, increases productivity and allows obtaining production in a continuous and uniform way, as well as good fruit quality (COSTA et al., 2009).

Figure $2 \mathrm{~b}$ shows that nitrogen fertilization level equivalent to $178 \mathrm{~kg} \mathrm{ha}^{-1}$ provided higher crop production, yielding 454 fruits per guava plant. This increase in crop yield points to a greater efficiency of this treatment about the others, which probably led this species to show different behavior according to the different nitrogen fertilization levels used in this study.

In this sense, Melo et al. (2010) reported that studies on mineral nutrition have shown high nutritional requirements and hence the importance of a balanced supply of nutrients to obtain economic productions. Carrijoetal. (2004) emphasized that nitrogen is present in the formation of various molecules of biological action such as nucleic acids, amino acids and proteins, playing a key role in the growth and development of plants, being perhaps the most influential element in crop production. However, according to Alves et al. (2010), special attention should be paid to the use of this nutrient, aimed at increasing the efficiency of its use, quantifying appropriate levels and knowing the magnitude and speed of their transformation, since according to Silva et al. (2003), the increase of $\mathrm{N}$ (from 0 to 1600 $\mathrm{kg} \mathrm{ha}^{-1}$ year ${ }^{-1}$ ) promoted reduction of about $10.61 \%$ in fruit yield.

The results corresponding to the total fruit weight per plant (TW), longitudinal diameter (LD) and shape index (SI), obtained as a function of the interaction between the different irrigation and nitrogen levels used in this study, can be observed in Tables 4 and 5 .

Table 4. Regression analysis of total water depths within nitrogen fertilization levels for variables total fruit weight per plant (TW), longitudinal diameter (LD) and shape index (SI)

\begin{tabular}{lcccc}
\hline & & \multicolumn{3}{c}{ Average square } \\
\cline { 3 - 5 } Source of variation & GL & TW & LD & SI \\
\hline Water depths $/ 50 \mathrm{~kg} \mathrm{ha}^{-1}$ & 3 & $337.78^{*}$ & $86.43^{\mathrm{ns}}$ & $72.25^{\mathrm{ns}}$ \\
Water depths $/ 100 \mathrm{~kg} \mathrm{ha}^{-1}$ & 3 & $1881.84^{* *}$ & $54.68^{\mathrm{ns}}$ & $37.75^{\mathrm{ns}}$ \\
Water depths $/ 150 \mathrm{~kg} \mathrm{ha}^{-1}$ & 3 & $2442.37^{* *}$ & $42.66^{\mathrm{ns}}$ & $114.22^{\mathrm{ns}}$ \\
Water depths $/ 200 \mathrm{~kg} \mathrm{ha}^{-1}$ & 3 & $666.57^{* *}$ & $230.73^{* *}$ & $96.75^{\mathrm{ns}}$ \\
\hline
\end{tabular}

$*$ and $* *$ significant at $1 \%$ and $5 \%$ probability, respectively, ns - not significant.

Table 5. Regression analysis of the nitrogen fertilization levels within water depths for variables total fruit weight per plant (TW), longitudinal diameter (LD) and shape index (SI)

\begin{tabular}{lcccc}
\multicolumn{1}{c}{ Source of variation } & GL & \multicolumn{3}{c}{ Average square } \\
\cline { 3 - 5 } & & TW & LD & SI \\
\hline Nitrogen levels $/ 1144 \mathrm{~mm}$ & 3 & $860.44^{* *}$ & $65.68^{\mathrm{ns}}$ & $281.06^{* *}$ \\
Nitrogen levels $/ 1465 \mathrm{~mm}$ & 3 & $268.11^{*}$ & $54.68^{\mathrm{ns}}$ & $49.23^{\mathrm{ns}}$ \\
Nitrogen levels $/ 1785 \mathrm{~mm}$ & 3 & $3450.47^{* *}$ & $42.66^{\mathrm{ns}}$ & $272.17^{* *}$ \\
Nitrogen levels $/ 2106 \mathrm{~mm}$ & 3 & $1058.47^{* *}$ & $230.73^{* *}$ & $56.73^{\mathrm{ns}}$ \\
\hline
\end{tabular}

$*$ and $* *$ significant at $1 \%$ and $5 \%$ probability, respectively, ns - not significant. 
Thus, it could be inferred that the guava culture responded positively to the combined application of factors at $5 \%$ probability level only when the lowest nitrogen fertilization level was applied, for the other levels, there was was significant effect at $1 \%$ probability level (Table 4 ). Regarding the results of the nitrogen fertilization level for each water depth (Table 5), there is a positive response to applications of nitrogen levels associated with different water depths at $5 \%$ probability level only when irrigation level corresponding to $1785 \mathrm{~mm}$ was applied, in other applications, significant effect at 5\% proba-

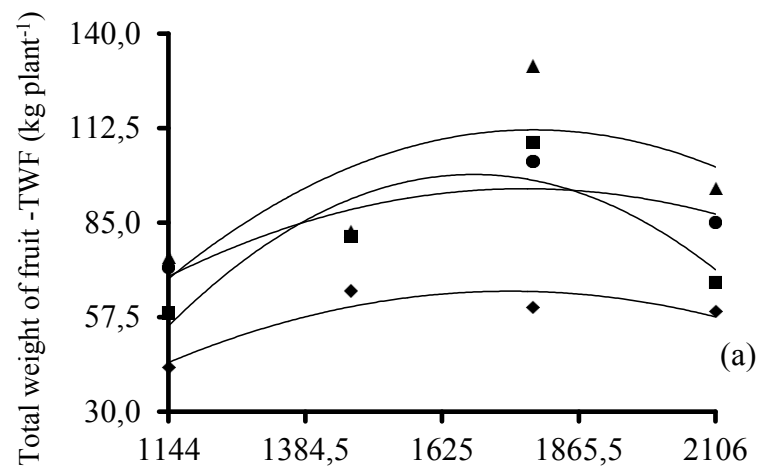

Total water depth: irrigation + precipitation $(\mathrm{mm})$

$\begin{array}{ccc}\bullet \mathrm{L}(\mathrm{N} 1) \bullet \mathrm{L}(\mathrm{N} 2) & \Delta \mathrm{L}(\mathrm{N} 3) & \bullet \mathrm{L}(\mathrm{N} 4) \\ \text { Regression equations } & \left(\mathrm{R}^{2}\right) \\ \mathrm{TWF}_{(\mathrm{LN} 1)}= & 9.6+0.2002 \mathrm{~L}-0.00006^{*} \mathrm{~L}^{2} & \mathrm{R}^{2}=0.81 \\ \mathrm{TWF}_{(\mathrm{LN} 2)}=333.09+0.514 \mathrm{~L}-0.00015^{* *} \mathrm{~L}^{2} & \mathrm{R}^{2}=0.84 \\ \mathrm{TWF}_{(\mathrm{LN} 3)}=223.4+0.3757 \mathrm{~L}-0.0001^{* *} \mathrm{~L}^{2} & \mathrm{R}^{2}=0.60 \\ \mathrm{TWF}_{(\mathrm{LN} 4)}=109.32+0.2308 \mathrm{~L}-0.00007^{* *} \mathrm{~L}^{2} & \mathrm{R}^{2}=0.72\end{array}$

bility was observed.

Figure $3 \mathrm{a}$ shows the influence of water depths and nitrogen fertilization levels on the total fruit weight per plant (TW). Thus, the highest values for this variable were obtained when nitrogen fertilization level equivalent to $150 \mathrm{~kg} \mathrm{ha}^{-1}$ was applied in combination with water depth corresponding to 1789 $\mathrm{mm}$, totaling $112.67 \mathrm{~kg}$ of fruits produced. It represents a $63.3 \%$ increase in the total fruit weight, starting from the lowest water depth applied, and 9.4\% compared to the maximum water depth adopted in this study.
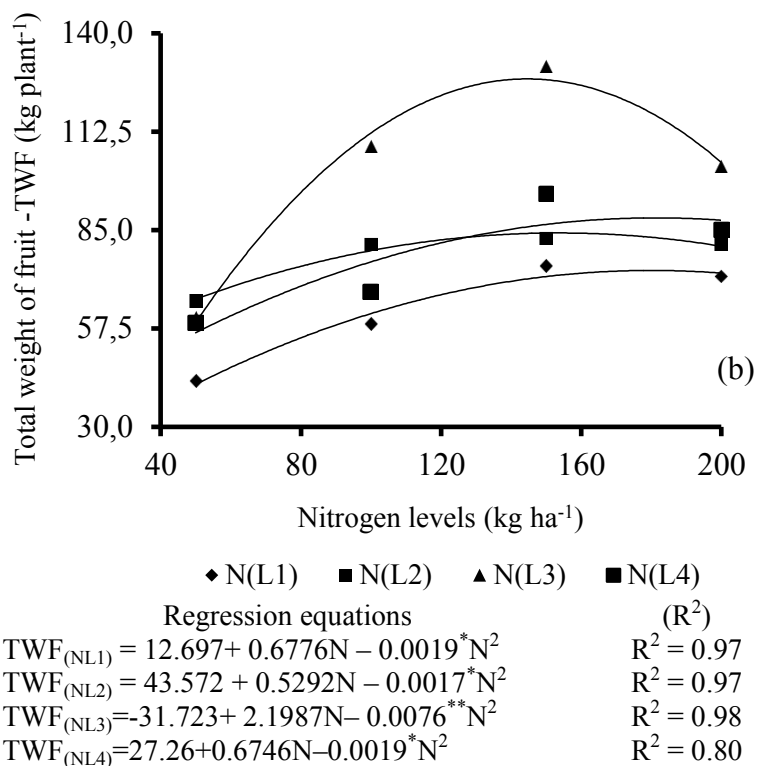

Figure 3. Total weight of guava fruit as a function of total water depths applied (a) and nitrogen fertilization levels (b)

By applying water depth corresponding to $1785 \mathrm{~mm}$ (Figure 3b), an increase in total fruit weight was observed, starting with the lowest nitrogen level with $59.46 \mathrm{~kg}$ to $129.42 \mathrm{~kg}$ at the maximum point of the model $\left(147 \mathrm{~kg}\right.$ of $\left.\mathrm{N} \mathrm{ha}^{-1}\right)$, providing an increase of $117.65 \%$ on the total fruit weight. From this point, the total fruit weight per plant decreased by $16.54 \%$ at the highest nitrogen fertilization level used (200 $\left.\mathrm{kg} \mathrm{ha}^{-1}\right)$.

According to the quadratic statistical model obtained for factor total water depth (Figure 4a), an increase in the average fruit weight of $0.163 \mathrm{~kg}$ was obtained using the lowest irrigation level (1144 mm) for $0.214 \mathrm{~kg}$ in the maximum point of the model, i.e., when irrigation level corresponding to $1750 \mathrm{~mm}$ was applied. These values provided an increase of $31.6 \%$ in the average weight of guava fruits. According to the quadratic model obtained for factor nitrogen fertilization levels (Figure 4b), it was observed that there was an increase in the average weight of guava fruits of $0.172 \mathrm{~kg}$ with the lowest nitrogen fertilization level, $50 \mathrm{~kg} \mathrm{ha}^{-1}$, up to $0.200 \mathrm{~kg}$ at the maximum point of the model $\left(152 \mathrm{~kg} \mathrm{ha}^{-1}\right)$, thus representing an increase of $16.3 \%$. Moreover, the use of the highest nitrogen fertilization level adopted in this study provided a decrease of $3.0 \%$ in the average weight of guava fruits from the maximum value estimated by the model $\left(152 \mathrm{~kg} \mathrm{ha}^{-1}\right)$.

These results corroborate those obtained by Carvalho and Nakagawa (2000), who emphasized that water is the primary constituent of plant cells; thus a means for the occurrence of essential physical and biochemical phenomena. Albrigo (1992) reported that increased soil moisture increases fruit size dilutes soluble solids and reduces acidity levels and other components. Its reduction, however, reduces photosynthesis, affecting the production of sugars and the growth of fruits, favoring their fall. According to Teixeira; Quaggio and Mellis (2011) when dealing with intensive agriculture, irrigation and fertilization are essential conditions for its implementation. Where there is an interaction between these factors, the application of fertilizers is strongly affected by soil water regimes. However, Alves et al. (2010) reported that the use of these sources requires improvements in the application techniques so that producers can obtain the maximum economic benefit when using fertilizers.

As for the equatorial diameter of guava fruits, Figure 5 shows quadratic effect at $1 \%$ probability level of factor total water depth, providing an increase in the equatorial diameter of guava fruits 
starting from $64.59 \mathrm{~mm}$ obtained with the application of water depth of $1144 \mathrm{~mm}$ to $71.58 \mathrm{~mm} \mathrm{ob-}$ tained when irrigation corresponding to $1805 \mathrm{~mm}$

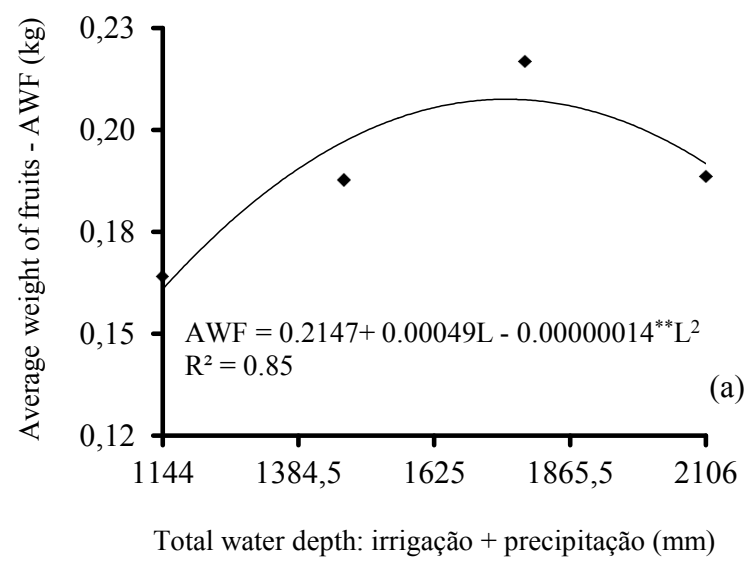

obtained at the maximum point of the statistical model was applied.

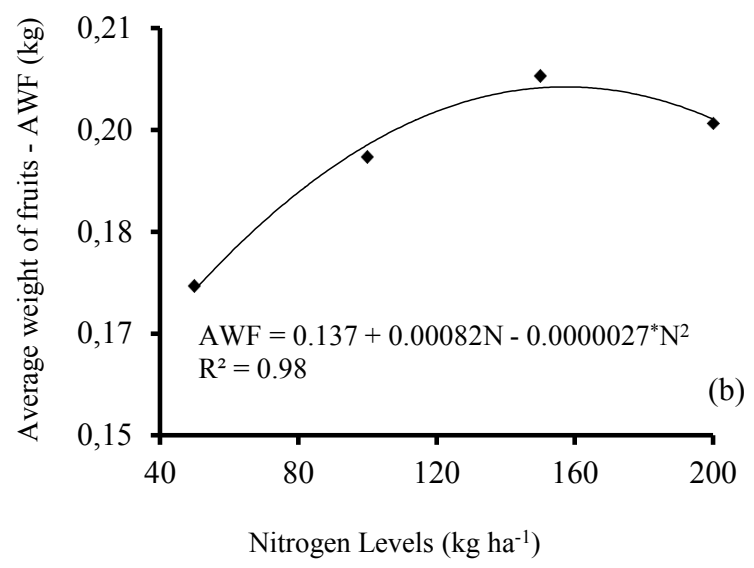

Figure 4. Average weight of guava fruits as a function of water depth (a) and nitrogen levels applied (b)

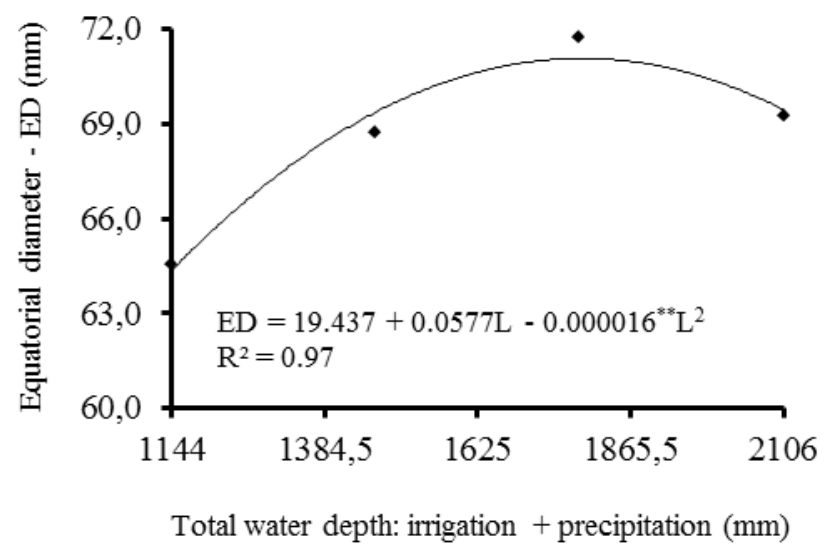

Figure 5. Equatorial diameter of guava fruits as a function of the water depths applied

Based on regression studies of water depths within each nitrogen level applied (Table 4), it was observed that the intensity of the effects of water depths in the longitudinal diameter (LD) on the fruit only occurred when using nitrogen level corresponding to $200 \mathrm{~kg} \mathrm{ha}^{-1}$; the other levels did not differ statistically as a function of water depths used. However, the nitrogen fertilization levels used for each water depth (Table 5) influenced the longitudinal diameter of guava fruits only when water depth of 2106 mm was applied.

According to the statistical model obtained (Figure 6a), it was observed that there was an increase in longitudinal diameter of guava fruits starting from the lowest water depth applied (1144 mm), with longitudinal diameter estimated from $76.62 \mathrm{~mm}$ to $91.01 \mathrm{~mm}$, obtained at the maximum point of the statistical model. This estimated maximum value represents an increase of 18.77, 14.76 and 12.05\%, respectively, in relation to water depths corresponding to 1144,1465 and $2106 \mathrm{~mm}$, which demonstrated a strong dependence on the amount of water supplied to the guava culture, since reducing the total water volume provided a reduction in the longitudinal diameter of fruits.
According to the amount of nitrogen applied to each water depth, Figure $6 \mathrm{~b}$ shows that the application of total water depth of $2106 \mathrm{~mm}$ resulted in a decrease of $1.59 \%$ when using $100 \mathrm{~kg} \mathrm{ha}^{-1}$ of $\mathrm{N}$, with longitudinal diameter of $83.71 \mathrm{~mm}$ in relation to the nitrogen fertilization level of $50 \mathrm{~kg} \mathrm{ha}^{-1}$, with 85.04 $\mathrm{mm}$ and an increase of 1.56 and $9.40 \%$, respectively, in relation to nitrogen levels corresponding to $150 \mathrm{~kg}$ $\mathrm{ha}^{-1}$, with $86.37 \mathrm{~mm}$ and $200 \mathrm{~kg} \mathrm{ha}^{-1}$, with longitudinal diameter of $93.04 \mathrm{~mm}$. It was also observed that the minimum value obtained for this variable was estimated to be $83.65 \mathrm{~mm}$ with the application of 92 $\mathrm{kg} \mathrm{ha}^{-1}$ of nitrogen.

In experiments with fertilized Paluma guava in semiarid Paraiba, Gouveia et al. (2004) found that the longitudinal and transversal diameter of fruits did not exceed 72.5 and $64.8 \mathrm{~mm}$, respectively. Lima, Assis e Gonzaga Neto (2002) observed that guava fruits grown in the São Francisco Valley showed longitudinal diameter between 58.4 and $76.0 \mathrm{~mm}$ and transversal diameter ranging from 53.0 to $77.9 \mathrm{~mm}$.

Due to the shape index of Paluma guava fruits, Figure 7 shows a significant effect of nitrogen fertilization levels, only when water depths corresponding to 1144 and $1785 \mathrm{~mm}$ were applied. Thus, 
the highest estimated shape index was 1.29 , which was obtained by the application of water depth of $1144 \mathrm{~mm}$ together with nitrogen fertilization level corresponding to $143 \mathrm{~kg} \mathrm{ha}^{-1}$. Moreover, when nitrogen fertilization level corresponding to $50 \mathrm{~kg} \mathrm{ha}^{-1}$ was used, increase of $13.0,15.9$ and $10 \%$ were ob-

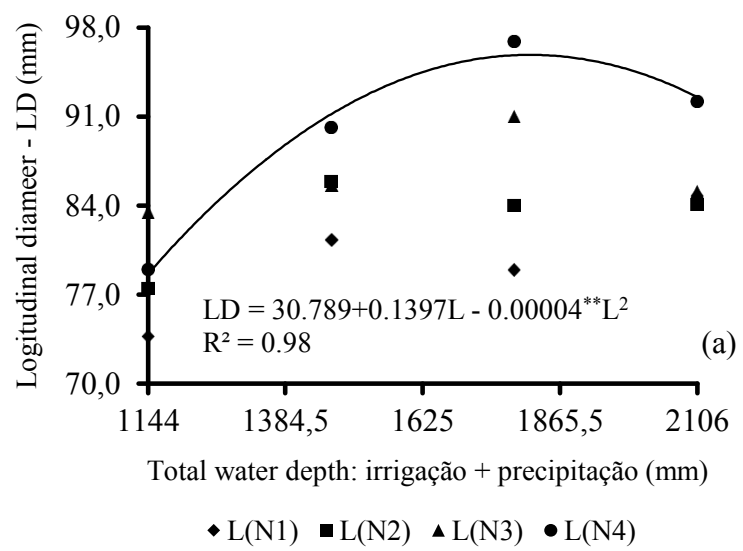

served, when compared with nitrogen fertilization levels corresponding to 100,150 and $200 \mathrm{~kg} \mathrm{ha}^{-1}$, respectively. For the total water depth of $1785 \mathrm{~mm}$, the linear statistical model obtained indicates that there was an increase in the shape index of fruits with the use of nitrogen fertilization.

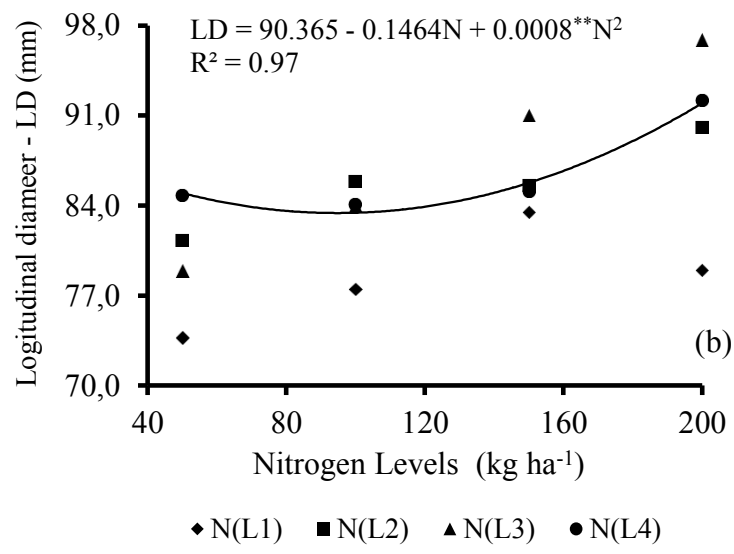

Figure 6. Longitudinal diameter of guava fruits as a function of water depths (a) and nitrogen fertilization levels applied (b)

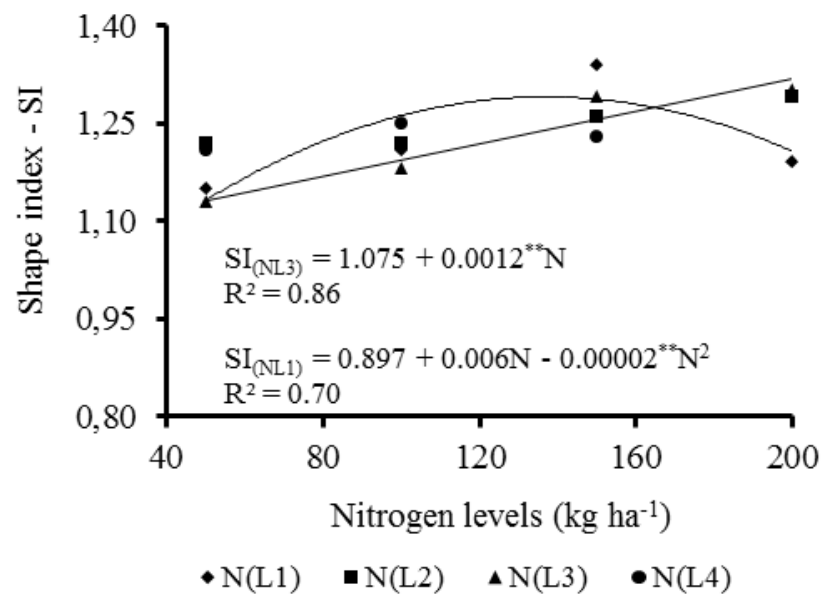

Figure 7. Shape index of guava fruits as a function of the nitrogen fertilization levels

The relationship between longitudinal and transverse diameters of fruits is used to determine their shape, where values close to 1.0 suggest rounder fruits (GERHARDT et al., 1997). In order to characterize guava fruits and select cultivars produced in the Lower Region of the São Francisco River, Lima; Assis and Gonzaga Neto (2002) found that the relationship between longitudinal and transverse diameters of fruits ranged from 0.98 to 1.25 , and the lowest ratios (0.98 to 1.02$)$ were obtained respectively in cultivars Banahas, Lucknow 49, Alabama Safed and R. S. Florida.

Based on the above, it is clear that the different irrigation and nitrogen fertilization levels applied, both in excess and in low amounts significantly influenced the characteristics of guava fruits. Moreover, when properly administered, the factors evaluated in this study proved to be a viable alternative, improving the physical attributes of guava fruits. Thus, Moura and Moura (2011) point out that fruit farming is an agricultural activity under the process of expansion, which has emerged as a segment of great socioeconomic importance. Several fruit trees compose the production systems in operation, among them mango, banana, vine, coconut, and guava stand out (GONZAGA NETO, 2002). Regarding the latter, cultivar Paluma is the most widespread cultured in Brazil, achieving productivity exceeding $50 \mathrm{t} \mathrm{ha}^{-1}$ year $^{-1}$ (LIMA; ASSIS; GONZAGA NETO, 2002).

\section{CONCLUSIONS}

The water depths corresponding to 1730 and $1750 \mathrm{~mm}$ increased production of fruits per plant and the average weight of guava fruit in, respectively, 25.1 and $31.6 \%$, whereas, the applications 178 and $152 \mathrm{~kg} \mathrm{~N} \mathrm{ha}^{-1}$ in creased at $67.1 \%$ in the production of fruits and $16.3 \%$ the average fruit weight;

The combined application of $150 \mathrm{~kg} \mathrm{~N} \mathrm{ha}{ }^{-1}$ and $1789 \mathrm{~mm}$ of water amounted to $63.3 \%$ of the 
total weight of guava fruit 'Paluma';

The equatorial diameter of the fruit was influenced by individual water depths applied evidencing an increase of up to $26.8 \%$. Already combinations $200 \mathrm{~kg} \mathrm{~N} \mathrm{ha}^{-1}$ and $1746 \mathrm{~mm}$ of water increased by $18.77 \%$ the longitudinal diameter of the fruits of guava;

The application of water depth to $1144 \mathrm{~mm}$, associated with143 $\mathrm{kg} \mathrm{N}^{-1}$ gave index of more satisfactory way to fruit guava.

\section{REFERENCES}

ALBRIGO, G. Influências ambientais no desenvolvimento dos frutos cítricos. In: SEMINÁRIO INTERNACIONAL DE CITRUS - FISIOLOGIA, 2, Campinas, 1992, Anais..., Campinas, p.100-105, 1992. 1. CD-ROM.

ALVES, M. S. et al. Crescimento e produtividade da bananeira cv. Grande Naine sob diferentes combinações de nitrato de cálcio e uréia. Revista Ceres, Viçosa, v. 57, n. 1, p. 125-131, 2010.

BLANEY, F. H.; CRIDDLE, W. D. Determining consumptive use and irrigation water requirements. Washington: United States Department of Agricultural, 1962. 93 p.

CARRIJO, O. A. et al. Fertirrigação de hortaliças. Brasília, DF: Embrapa Hortaliças, 2004. (Circular Técnica da Embrapa Hortaliças, 32).

CARVALHO, C. M. et al. Desempenho de um sistema de irrigação por gotejamento na cultura da goiaba. Revista Irriga, Botucatu, v. 11, n. 1, p. 36-46, 2006.

CARVAlHO, N. M.; NAKAGAWA, J. Sementes: ciências, tecnologia e produção. 2.ed. CampinasSP: Fundação Cargill, 2000. 565 p.

COSTA, S. C. et al. Comportamento dos parâmetros indicativos de produção da bananeira pacovan submetida a diferentes lâminas de irrigação e doses de potássio na Chapada do Apodi, Limoeiro do NorteCe. Revista Caatinga, Mossoró, v. 22, n. 4, p. 4652, 2009.

FARIAS, C. H. A. et al. Crescimento e desenvolvimento da cultura do melão sob diferentes lâminas de irrigação e salinidade da água. Revista Brasileira de Engenharia Agrícola e Ambiental, Campina Grande, v. 7, n. 3, p. 445-450, 2003.

FREITAS, W. S.; RAMOS, M. M.; COSTA, S. L. Demanda de irrigação da cultura da banana na bacia do Rio São Francisco. Revista Brasileira de Engenharia Agrícola e Ambiental, Campina Grande, v.
12, n. 4, p. 343-349, 2008.

GERHARDT, L. B. A. et al. Características físicoquímicas dos frutos de quatro cultivares e três clones de goiabeira em Porto Lucena, RS. Pesquisa Agropecuária Brasileira, Brasília, v. 32 , n. 2, p. 185 192, 1997.

GONZAGA NETO, L. Introdução e avaliação de clones de goiabeira de polpa Branca (Psidium guaja$v a$ L.) Na região do submédio são Francisco. Revista Brasileira de Fruticultura, Jaboticabal, v. 24, n. 1, p. 120-123, 2002.

GOUVEIA, J. P. G. et al. Determinação de características físico-químicas da goiaba: Goiabeiras adubadas no semiárido da Paraíba. Revista Brasileira de Produtos Agroindustriais, Campina Grande, v. 6, n. 1, p. 35-38, 2004.

LIMA, M. A. C.; ASSIS, J. S.; GONZAGA NETO, L. Caracterização dos frutos de goiabeira e seleção de cultivares na região do Submédio São Francisco. Revista Brasileira de Fruticultura, Jaboticabal, v. 24, n. 1, p. 273-276, 2002.

LOUSADA JÚNIOR, J. E. et al. Caracterização físico-química de subprodutos obtidos do processamento de frutas tropicais visando seu aproveitamento na alimentação animal. Revista Ciência Agronômica, Fortaleza, v. 37, n. 1, p. 70-76, 2006.

MACIEL, J. L.; DANTAS NETO, J.; FERNANDES, P. D. Resposta da goiabeira à lâmina de água e à adubação nitrogenada. Revista Brasileira de Engenharia Agrícola e Ambiental, Campina Grande, v. 11 , n. 6 , p. 571-577, 2007.

MELO, A. S. et al. Aspectos técnicos e econômicos da bananeira 'prata-anã' sob fertirrigação nos tabuleiros costeiros de Sergipe. Revista Ciência e Agrotécnologia, Fortaleza, v. 34, n. 3, p. 564-571, 2010.

MOURA, A. P.; MOURA, D. C. M. Levantamento e flutuação populacional de parasitoides de moscasdas-frutas (Diptera: Tephritidae) de ocorrência em goiabeira (Psidium Guajava L.) em Fortaleza, Ceará. Arquivos do Instituto Biológico, São Paulo, v. 78, n. 2, p. 225-231, 2011.

PEIXOTO, J. F. S.; GUERRA, H. O. C.; CHAVES, L. H. G. Alterações de atributos químicos do solo pela fertirrigação com nitrogênio e potássio. Revista Agropecuária Técnica, Areia, v. 27, n. 2, p. 69-76, 2006.

PEREIRA, F. M.; CARVALHO, C. A.; NACHTIGAL, J. C. Século XXI: nova cultivar de goiabeira de dupla finalidade. Revista Brasileira de Fruticultura, Jaboticabal, v. 25, n. 3, p. 498-500, 2003. 
ROZANE, D. E.; OLIVEIRA, D. A.; LIRIO, V. S. Importância econômica da cultura da goiabeira. In: ROZANE, D. E.; COUTO, F. A. D. (ed.). Cultura da goiabeira: Tecnologia e mercado. Viçosa: UFV, 2003. p.1-20.

SILVA, J. T. A. et al. Adubação com potássio e nitrogênio em três ciclos de produção da bananeira cv. Prata-Anã. Revista Brasileira de Fruticultura, Jaboticabal, v. 25, n. 1, p. 152-155, 2003.

SOBEL, T. F.; COSTA, E. F. Estimando taxas de adoção de tecnologias poupadoras de água na fruticultura irrigada do Vale do São Francisco: o caso dos pequenos agricultores. Revista Econômica do Nordeste, Fortaleza, v. 36, n. 1, p. 121-146, 2005.

TEIXEIRA, L. A. J.; QUAGGIO, J. A.; MELLIS, E. V. Ganhos de eficiência fertilizante em bananeira sob irrigação e fertirrigação. Revista Brasileira de Fruticultura, Jaboticabal, v. 33, n. 1, p. 272-278, 2011.

XAVIER, L. F.; COSTA, R. F.; COSTA, E. F. Adoção de tecnologias poupadoras de água na fruticultura irrigada do Vale do São Francisco: uma comparação entre percepções de colonos e empresas. Revista de Economia Rural, Brasília, v. 44, n. 2, p. 219241, 2006. 